\title{
BIOLOGI REPRODUKSI DAN TINGKAT KEBERHASILAN PEMIJAHAN IKAN BAUNG Hemibagrus nemurus (Valenciennes, 1840) POPULASI CIRATA DENGAN INKUBASI SUHU BERBEDA
}

\author{
Deni Radona\#, Jojo Subagja, Vitas Atmadi Prakoso, Irin Iriana Kusmini, dan Anang Hari Kristanto \\ Balai Riset Perikanan Budidaya Air Tawar dan Penyuluhan Perikanan \\ Jl. Sempur No. 1, Bogor 16129
}

(Naskah diterima: 5 April 2018; Revisi final: 16 Mei 2018; Disetujui publikasi: 16 Mei 2018)

\begin{abstract}
ABSTRAK
Ikan baung merupakan salah satu komoditas populer di Indonesia. Dalam pengembangan budidayanya masih diperlukan input teknologi terutama pada proses pembenihan. Penelitian ini bertujuan untuk mengevaluasi karakter biologi reproduksi dan keberhasilannya dalam proses pemijahan pada ikan baung populasi Cirata yang diinkubasi pada suhu $23^{\circ} \mathrm{C}-24^{\circ} \mathrm{C}, 25^{\circ} \mathrm{C}-26^{\circ} \mathrm{C}, 27^{\circ} \mathrm{C}-28^{\circ} \mathrm{C}$, dan $29^{\circ} \mathrm{C}-30^{\circ} \mathrm{C}$. Inkubasi induk dilakukan pada styrofoam berukuran $45 \mathrm{~cm} \times 35 \mathrm{~cm} \times 25 \mathrm{~cm}$ dengan ketebalan $3 \mathrm{~cm}$. Setiap styrofoam diisi satu ekor induk yang matang gonad. Seleksi tingkat kematangan gonad dilakukan secara kanulasi dan induksi hormon menggunakan LHRH analog $(0,6 \mathrm{~mL} / \mathrm{kg})$. Penyuntikan dilakukan dua kali dengan selang waktu enam jam. Styrofoam diisi air dengan ketinggian $20 \mathrm{~cm}$, dilengkapi tutup pada bagian atas, water heater, dan sistem aerasi. Inkubasi suhu dilakukan secara eksperimental menggunakan rancangan acak lengkap dengan empat perlakuan suhu dan masing-masing perlakuan diulang sebanyak tiga kali. Hasil penelitian menunjukkan suhu optimal inkubasi pada induk yaitu $27^{\circ} \mathrm{C}-28^{\circ} \mathrm{C}$ dengan waktu laten 8 jam 35 menit, dan derajat ovulasi $100 \%$ Secara statistik inkubasi induk pada suhu $27^{\circ} \mathrm{C}-28^{\circ} \mathrm{C}$ menunjukkan nilai karakter biologi reproduksi yang berbeda nyata $(P<0,05)$ dibandingkan dengan inkubasi suhu $23^{\circ} \mathrm{C}-24^{\circ} \mathrm{C}$ dan $25^{\circ} \mathrm{C}-26^{\circ} \mathrm{C}$. Nilai biologi reproduksi yang dihasilkan pada perlakuan terbaik tersebut adalah indeks kematangan gonad $8,6 \pm 0,5 \%$ fekunditas $23.909 \pm 1.473$ butir per ekor; derajat pembuahan $85,5 \pm$ $5,5 \%$ derajat penetasan $69,9 \pm 5,0 \%$ dan sintasan $72,3 \pm 5,8 \%$ Pada inkubasi suhu $27 \mathrm{C}^{\circ}-28^{\circ} \mathrm{C}$, telur terdistribusi dengan diameter telur rata-rata sebesar $1,5 \mathrm{~mm}$.
\end{abstract}

KATA KUNCl: $\quad$ ikan baung; inkubasi; suhu; reproduksi; pemijahan

ABSTRACT: Reproductive biology and level of spawning of Asian redtail catfish Hemibagrus nemurus (Valenciennes, 1840) from Cirata population incubated at different temperature settings. By: Deni Radona, Jojo Subagja, Vitas Atmadi Prakoso, Irin Iriana Kusmini, and Anang Hari Kristanto

Asian redtail catfish is one of the most popular fish commodities in Indonesia. However, improvements in its aquaculture technology are still needed, especially in the breeding process. This study was aimed to evaluate the characters of reproductive biology and level of spawning on Asian redtail catfish from Cirata population incubated at different temperature settings of $23^{\circ} \mathrm{C}-24^{\circ} \mathrm{C}, 25^{\circ} \mathrm{C}-26^{\circ} \mathrm{C}, 27^{\circ} \mathrm{C}-28^{\circ} \mathrm{C}$, and $29^{\circ} \mathrm{C}-30^{\circ} \mathrm{C}$. Broodstock incubation was conducted in styrofoam boxes (sized $45 \mathrm{~cm} \times 35 \mathrm{~cm} \times 25 \mathrm{~cm}$ ) with a wall thickness of $3 \mathrm{~cm}$. One mature broodstock was placed inside each Styrofoam. Each styrofoam box was previously filled with freshwater of $20 \mathrm{~cm}$ deep, equipped with a lid on top, a water heater, and an aeration system. The gonad maturity stage of each broodstock was determined using cannulation, whilst the hormone induction used LHRH hormone analog $(0.6 \mathrm{~mL} / \mathrm{kg})$. The injection was performed twice within six hours interval. The incubation was arranged in a completely randomized design (CRD) with four temperature treatments with three replicates. The results showed that the optimal incubation temperature for the broodstock was $27^{\circ} \mathrm{C}-28^{\circ} \mathrm{C}$ with the latent time ovulation of 8 hours 35 minutes and an ovulation rate of $100 \%$ Statistically, the incubation of broodstock at $27^{\circ} \mathrm{C}-28^{\circ} \mathrm{C}$ showed a significant difference on the reproductive biological character value $(\mathrm{P}<0.05)$ compared to temperature ranges at $23^{\circ} \mathrm{C}-24^{\circ} \mathrm{C}$ and $25^{\circ} \mathrm{C}-26^{\circ} \mathrm{C}$. The reproductive biology

\footnotetext{
\# Korespondensi: Balai Riset Perikanan Budidaya Air Tawar dan Penyuluhan Perikanan. Jl. Sempur No. 1, Bogor 16129, Indonesia.

Tel. + 622518313200

E-mail: deniradona_kkp@yahoo.com
} 
parameters generated were gonadosomatic index of $8.6 \pm 0.5 \%$ fecundity of $23,909 \pm 1,473$ egg per individual; fertilization rate of $85.5 \pm 5.5 \%$ hatching rate of $69.9 \pm 5.0 \%$ and survival rate of $72.3 \pm 5.8 \%$ At the incubation temperature of $27^{\circ} \mathrm{C}-28^{\circ} \mathrm{C}$, the egg was distributed with an average egg diameter of $1.5 \mathrm{~mm}$.

\section{KEYWORDS: Asian redtail catfish; incubation; temperature; reproduction; spawning}

\section{PENDAHULUAN}

Ikan baung Hemibagrus nemurus merupakan salah satu sumber daya genetik dari 22 jenis ikan air tawar di Indonesia yang dapat digunakan untuk diversifikasi usaha budidaya (Gustiano et al., 2015). Ikan ini bernilai ekonomis karena memiliki kualitas daging dan nilai gizi baik. Di pasar nasional harga ikan baung per $\mathrm{kg}$ berkisar Rp30.000,00-Rp40.000,00. Sejauh ini dalam memenuhi kebutuhan konsumsi maupun penyediaan benih untuk kegiatan pembesaran masih mengandalkan tangkapan dari alam (Leesa-Nga et al., 2000). Di Indonesia, pemijahan ikan baung pertama kali dilakukan pada tahun 1983 secara alami, sedangkan pemijahan secara buatan baru dilakukan pada tahun 1991 dengan menggunakan hormon ekstrak kelenjar hifopisa ikan mas Cyprinus carpio dan Human Chorionic Gonadotrophin (HCG) (Gaffar \& Muflikhah, 1992). Pengembangan teknologi pemijahan baru dilakukan pada tahun 2000 an, pemijahan ikan baung sudah menggunakan teknologi rangsangan hormon Luteunizing Hormon Realising Hormon (LHRH) analog kombinasi dengan anti-dopamin.

Sampai saat ini, dalam pengembangan budidaya ikan baung masih banyak terdapat kendala dan permasalahan terutama pada proses pembenihan. Kegagalan induk betina dalam berovulasi menjadi penyebab utama menurunnya produktivitas. Untuk itu, diperlukan usaha dalam memperbaiki pengelolaan dan manajemen induk untuk meningkatkan performa pemijahan, salah satunya dengan menjaga kondisi lingkungan perairannya yaitu suhu. Suhu merupakan salah satu faktor yang dapat memengaruhi proses fisiologi dan reproduksi pada ikan (Migaud et al., 2013; Pankhurst \& Munday, 2011; Brian et al., 2008; Korner et al., 2008). Suhu air yang berfluktuasi sering menjadi penghambat dalam proses pematangan gonad (Vikingstad et al., 2008) dan proses waktu jalannya pemijahan (Nowosad et al., 2014). Untuk itu, diperlukan teknologi inkubasi induk pada suhu optimal dalam upaya mempertahankan kualitas telur dan mempercepat proses ovulasi. Penelitian pendahuluan terkait inkubasi induk pada ikan baung sudah dilakukan Kristanto et al. (2016), dari hasil penelitian memperlihatkan ada pengaruh yang nyata pada kinerja reproduksi ikan. Namun pada penelitian tersebut, proses inkubasi ketiga induk ikan baung yang mewakili ulangan dari perlakukan penelitian dilakukan di dalam wadah yang sama.

Tujuan dari penelitian ini adalah untuk mengevaluasi karakter biologi reproduksi dan keberhasilan proses pemijahan pada ikan baung populasi Cirata yang diinkubasi suhu berbeda.

\section{BAHAN DAN METODE}

\section{Ikan Uji}

Ikan uji yang digunakan dalam penelitian ini berupa induk betina dedara ikan baung populasi Cirata hasil domestikasi. Induk berukuran panjang 28,86 $\pm 0,77$ $\mathrm{cm}$; dan bobot 326,67 $\pm 12,47 \mathrm{~g}$; merupakan ikan koleksi di Instalasi Riset Plasma Nutfah Perikanan Air Tawar Cijeruk. Induk yang digunakan sebanyak 12 ekor dengan tingkat kematangan gonad akhir (TKG IV). Seleksi tingkat kematangan gonad dilakukan dengan metode kanulasi dan dilakukan induksi hormon dengan menggunakan LHRH analog dosis $0,6 \mathrm{~mL} / \mathrm{kg}$. Penyuntikan dilakukan dua kali dengan selang waktu enam jam. Sampel ikan berasal dari satu kelompok umur yang sama dan dipelihara dal am lingkungan yang sama.

\section{Inkubasi Induk}

Inkubasi induk dilakukan dengan menggunakan styrofoam berukuran $45 \mathrm{~cm} \times 35 \mathrm{~cm} \times 25 \mathrm{~cm}$, ketebalan $3 \mathrm{~cm}$ dan diisi air setinggi $20 \mathrm{~cm}$. Setiap styrofoam diisi satu ekor induk. Styrofoam dilengkapi tutup pada bagian atas, water heater, dan sistem aerasi. Inkubasi induk untuk mendapatkan suhu optimal dilakukan secara eksperimental menggunakan rancangan acak lengkap dengan empat perlakuan suhu, yaitu (A) $23^{\circ} \mathrm{C}$ $24^{\circ} \mathrm{C}$, (B) $25^{\circ} \mathrm{C}-26^{\circ} \mathrm{C}$, (C) $27^{\circ} \mathrm{C}-28^{\circ} \mathrm{C}$, dan (D) $29^{\circ} \mathrm{C}-30^{\circ} \mathrm{C}$. Masing-masing perlakuan diulang sebanyak tiga kali.

\section{Karakter Biologi Induk}

Karakterisasi biologi induk dilakukan setelah perlakuan inkubasi pada suhu berbeda. Parameter yang diamati adalah waktu laten ovulasi (jam), derajat ovulasi ( $\%$, bobot gonad $(\mathrm{g})$, indeks kematangan gonad [IKG] (\%); dan fekunditas (butir per ekor). Pengamatan bobot gonad dan IKG dilakukan dengan menimbang gonad total, sedangkan fekunditas dihitung berdasarkan metode gravimetrik (Effendie, 2002). 


\section{Kinerja Reproduksi}

Kinerja reproduksi induk ikan baung diamati setelah proses ovulasi dilakukan. Parameternya adalah derajat pembuahan (\%); derajat penetasan (\%); dan sintasan (\%. Sebanyak 150 butir telur yang telah dibuahi ditebar ke dalam basket berukuran $12 \mathrm{~cm} \times 10 \mathrm{~cm} \times 5$ $\mathrm{cm}$ dengan ketinggian air sekitar $3 \mathrm{~cm}$. Basket yang digunakan sebanyak 12 buah, mewakili dari empat perlakuan dan tiga ulangan. Nilai derajat pembuahan diamati dua jam setelah fertilisasi, derajat penetasan diamati setelah 30 jam pembuahan, sedangkan sintasan diamati setelah dua hari penetasan.

\section{Analisis Data}

Parameter biologi reproduksi yang diamati diukur menggunakan rumus Effendie (2002) dan Murtidjo (2001). Data yang diperoleh kemudian ditabulasi dan dianalisis dengan analisis varian (ANOVA) pada selang kepercayaan $95 \%$ Perbedaan antar perlakuan dianalisis lanjut dengan uji lanjut Duncan menggunakan bantuan program SPSS versi 18.

\section{HASIL DAN BAHASAN}

\section{Karakter Biologi Induk}

Waktu laten dan derajat ovulasi ikan baung populasi Cirata disajikan pada Tabel 1, sedangkan karakterisasi biologi induk yang meliputi panjang, bobot, bobot gonad, IKG dan fekunditas disajikan pada Tabel 2.
Berdasarkan hasil pengamatan dari 12 induk ikan baung yang dilakukan pemijahan diperoleh 10 ekor yang mengalami ovulasi. Induk dengan inkubasi suhu $27^{\circ} \mathrm{C}-28^{\circ} \mathrm{C}$ memiliki waktu ovulasi rata-rata delapan jam dengan derajat ovulasi $100 \%$ Dari hasil perlakuan inkubasi suhu menunjukkan bahwa inkubasi induk dengan suhu $27^{\circ} \mathrm{C}-28^{\circ} \mathrm{C}$ dan $29^{\circ} \mathrm{C}-30^{\circ} \mathrm{C}$ memiliki nilai IKG dan fekunditas yang tidak berbeda nyata $(P>0,05)$; namun berbeda dengan perlakuan inkubasi pada suhu $23^{\circ} \mathrm{C}-24^{\circ} \mathrm{C}$. Suhu merupakan faktor penting dalam memengaruhi proses biologi dan kehidupan ikan (Targonska et al., 2010). Menurut Schulte (2011), suhu memiliki pengaruh besar terhadap proses biologi suatu organisme dari ukuran sel hingga ekosistem, karena hal yang dipengaruhi adalah tingkat reaksi biologi dan keseimbangan interaksi intermolekuler. Selain itu, suhu juga dapat memengaruhi perkembangan kematangan gonad dan berperan dalam menghasilkan telur pada ikan (Migaud et al., 2013; Pankhurst \& Munday, 2011; Vikingstad et al., 2008).

Suhu inkubasi yang optimal akan menghasilkan telur dengan kualitas dan ukuran telur yang homogen, sebaliknya induk ikan baung yang diinkubasi dengan suhu yang rendah akan menurunkan kualitas telur dan ukuran yang tidak seragam (Kucharczyk et al., 2014: Nowosad et al., 2015). Rendahnya kual itas dan ukuran telur pada ikan terjadi karena menurunnya plasma 17âestradiol (E2) dalam tubuh dan proses sekresinya tidak berjalan secara optimal karena pengaruh suhu yang

Tabel 1. Waktu laten dan derajat ovulasi, serta tingkat keberhasilan pemijahan buatan induk ikan baung dengan inkubasi suhu berbeda

Table 1. Latent time of ovulation, ovulation rate and successful level of artificial spawning on Asian redtail catfish with different incubation temperatures

\begin{tabular}{|c|c|c|c|c|}
\hline $\begin{array}{l}\text { Perlakuan suhu } \\
\text { Temperature } \\
\text { treatment } \\
\text { (ㄷ) }\end{array}$ & $\begin{array}{l}\text { Waktu laten ovulasi (jam) } \\
\text { pascainduksi-I } \\
\text { Latent time of ovulation (hours) } \\
\text { post induction-II }\end{array}$ & $\begin{array}{c}\text { Rata-rata waktu ovulasi } \\
\text { Average ovulation time } \\
\text { (jam/hours ) }\end{array}$ & $\begin{array}{l}\text { Keterangan } \\
\text { pemijahan } \\
\text { Spawning } \\
\text { information }\end{array}$ & $\begin{array}{c}\text { Derajat ovulasi } \\
\text { Ovulation rate } \\
(\%)\end{array}$ \\
\hline \multirow{3}{*}{$23-24$} & - & & Tidak (No) & \\
\hline & 13.5 & $11.3 \pm 2.3$ & Ya (Yes) & 66.6 \\
\hline & 9 & & Ya (Yes) & \\
\hline \multirow{3}{*}{$25-26$} & 9 & & Ya (Yes) & \\
\hline & 5.5 & $7.3 \pm 1.8$ & Ya (Yes) & 66.6 \\
\hline & - & & Tidak (No) & \\
\hline \multirow{3}{*}{$27-28$} & 8.3 & & Ya (Yes) & \\
\hline & 9.5 & $8.6 \pm 0.7$ & Ya (Yes) & 100 \\
\hline & 8 & & Ya (Yes) & \\
\hline \multirow{3}{*}{$29-30$} & 5.5 & & Ya (Yes) & \\
\hline & 12.5 & $8.7 \pm 2.9$ & Ya (Yes) & 100 \\
\hline & 8 & & Ya (Yes) & \\
\hline
\end{tabular}


Tabel 2. Karakteristik induk ikan baung dengan inkubasi pada suhu berbeda

Table 2. Characteristics of Asian redtail catfish broodstock subjected to different incubation temperature

\begin{tabular}{|c|c|c|c|c|c|c|c|}
\hline $\begin{array}{l}\text { Perlakuan suhu } \\
\text { Temperature } \\
\text { treatment } \\
\left({ }^{\circ} \mathrm{C}\right)\end{array}$ & $\begin{array}{l}\text { Panjang } \\
\text { Length } \\
(\mathbf{c m})\end{array}$ & $\begin{array}{c}\text { Bobot } \\
\text { Weight } \\
\text { (g) }\end{array}$ & $\begin{array}{c}\text { Bobot gonad } \\
\text { Gonad weight } \\
\text { (g) }\end{array}$ & $\begin{array}{l}\text { IKG } \\
\text { (\%) }\end{array}$ & $\begin{array}{c}\text { Rata-rata IKG } \\
\text { Average of IKG } \\
\text { (\%) }\end{array}$ & $\begin{array}{c}\text { Fekunditas } \\
\text { (butir/100 g induk) } \\
\text { Fecundity } \\
\text { (egg/100 } \mathrm{g} \text { of broodstock) }\end{array}$ & $\begin{array}{l}\text { Rata-rata fekunditas } \\
\text { (butir/100 g induk) } \\
\text { Average of fecundity } \\
\text { (egg/100 g of broodstock) }\end{array}$ \\
\hline \multirow{3}{*}{$23-24$} & 25.6 & 300 & - & - & & - & \\
\hline & 26.5 & 340 & 17.8 & 5.1 & $4.8 \pm 0.3^{\mathrm{a}}$ & 5.204 & $4.873 \pm 332^{\mathrm{a}}$ \\
\hline & 26.3 & 300 & 13.5 & 4.5 & & 4.540 & \\
\hline \multirow{3}{*}{$25-26$} & 27.5 & 340 & 28.9 & 8.5 & & 7.212 & \\
\hline & 25 & 300 & 20.9 & 7 & $7.7 \pm 0.8^{b}$ & 6.179 & $6.696 \pm 517^{b}$ \\
\hline & 27.5 & 340 & - & - & & - & \\
\hline \multirow{3}{*}{$27-28$} & 25 & 300 & 25.1 & 8.4 & & 8.349 & \\
\hline & 25.5 & 320 & 26.1 & 8.2 & $8.6 \pm 0.5^{b}$ & 6.821 & $7.818 \pm 705^{b c}$ \\
\hline & 26 & 300 & 27.9 & 9.3 & & 8.282 & \\
\hline \multirow{3}{*}{$29-30$} & 26.5 & 320 & 28.9 & 9 & & 8.706 & \\
\hline & 26.3 & 320 & 27.9 & 8.7 & $8.6 \pm 0.4^{b}$ & 8.457 & $8.272 \pm 450^{c}$ \\
\hline & 25 & 320 & 25.8 & 8.1 & & 7.651 & \\
\hline
\end{tabular}

Keterangan: Angka yang diikuti huruf superskrip yang sama pada lajur yang sama menunjukkan tidak adanya perbedaan nyata menurut Uji Duncan $(P>0,05)$

Remarks: $\quad$ Numbers followed by the same superscript letter in the same line indicates no significantly difference $(P>0.05)$

terlalu rendah (Lahnsteiner \& Leitner, 2013; Pankhurst $\&$ King, 2010). Telur dengan kualitas baik akan mengalami proses embriogenesis dan organogenesis yang baik sehingga menghasilkan larva yang berkualitas.

\section{Kinerja Reproduksi}

Kinerja reproduksi yang meliputi derajat pembuahan, penetasan, dan sintasan disajikan pada Tabel 3. Dari hasil pengamatan kinerja reproduksi induk ikan baung diperoleh hasil dengan nilai reproduksi tertinggi pada perlakuan inkubasi pada suhu $27^{\circ} \mathrm{C}-28^{\circ} \mathrm{C}$, yaitu derajat pembuahan $(85,5 \pm 5,5 \%$; derajat penetasan $(69,9 \pm 5,0 \%)$; dan sintasan $(72,3 \pm 5,8 \%$. Secara statistik nilai tersebut menunjukkan perbedaan secara nyata $(P<0,05)$ dengan perlakuan inkubasi pada suhu $23^{\circ} \mathrm{C}-24^{\circ} \mathrm{C}$.

Suhu berperan penting dalam waktu pemijahan dan siklus reproduksi pada ikan (Hilder \& Pankhurst, 2003; Brian et al., 2008; Korner et al., 2008). Suhu akan memengaruhi proses reproduksi melalui hipotalamuspituitari-gonad. Hormon gonadotropin disentesis di

Tabel 3. Kinerja reproduksi induk ikan baung dengan inkubasi pada suhu berbeda

Table 3. Reproduction performance of Asian redtail catfish broodstock subjected to different incubation temperaturesettings

\begin{tabular}{cccc}
\hline $\begin{array}{c}\text { Perlakuan suhu } \\
\begin{array}{c}\text { Temperature treatment } \\
\left({ }^{\circ} \mathbf{C}\right)\end{array}\end{array}$ & $\begin{array}{c}\text { Rata-rata derajat pembuahan } \\
\text { Average of fertilization rate } \\
(\%)\end{array}$ & $\begin{array}{c}\text { Rata-rata derajat penetasan } \\
\text { Average of hatching rate } \\
(\%)\end{array}$ & $\begin{array}{c}\text { Rata-rata sintasan } \\
\text { Average of survival rate } \\
(\%)\end{array}$ \\
\hline $23-24$ & $69.8 \pm 1.3^{\mathrm{a}}$ & $46.3 \pm 4.0^{\mathrm{a}}$ & $37.9 \pm 2.2^{\mathrm{a}}$ \\
$25-26$ & $84.6 \pm 4.9^{\mathrm{b}}$ & $54.6 \pm 4.9^{\mathrm{ab}}$ & $54.2 \pm 13.8^{\mathrm{ab}}$ \\
$27-28$ & $85.5 \pm 5.5^{\mathrm{b}}$ & $69.9 \pm 5.0^{\mathrm{c}}$ & $72.3 \pm 5.8^{\mathrm{b}}$ \\
$29-30$ & $80.8 \pm 6.4^{\mathrm{ab}}$ & $60.5 \pm 1.8^{\mathrm{bc}}$ & $64.7 \pm 6.8^{\mathrm{b}}$ \\
\hline
\end{tabular}

Keterangan: Angka yang diikuti huruf superskrip yang sama pada lajur yang sama menunjukkan tidak adanya perbedaan nyata menurut Uji Duncan $(P>0,05)$

Remarks: Numbers followed by the same superscript letter in the same line indicates no significantly difference $(P>0.05)$ 
kelenjar hipotalamus (Levavi-Sivan et al., 2010; Zohar et al., 2010). Pada penelitian ini diperoleh suhu inkubasi yang optimal $27^{\circ} \mathrm{C}-28^{\circ} \mathrm{C}$. Inkubasi induk dengan suhu relatif rendah akan menghambat proses fisologi dan metabolisme, sedangkan inkubasi dengan suhu tinggi dapat memengaruhi ovulasi dini, perkembangan gonad yang tidak normal dan resorpsi telur (Nowosad et al., 2015; Pankhurst \& King, 2010).

\section{KESIMPULAN}

Inkubasi induk ikan baung pada suhu $27^{\circ} \mathrm{C}-28^{\circ} \mathrm{C}$ memberikan hasil yang nyata pada karakter biologi reproduksi (IKG, fekunditas, derajat pembuahan, derajat penetasan, dan sintasan) dengan keberhasilan pemijahan (derajat ovulasi) sebesar $100 \%$

\section{UCAPAN TERIMA KASIH}

Ucapan terima kasih disampaikan kepada Balai Riset Perikanan Budidaya Air Tawar dan Penyuluhan Perikanan karena sudah mendanai kegiatan ini melalui APBN 2017. Terima kasih juga kepada Ibu Dr. Ani Widiyati atas saran dan masukannya dalam penulisan makalah ini, kepada Bapak Otong Zenal Arifin atas fasilitas penelitiannya, dan kepada Bapak Sudarmaji, Ujang Heri Heryana, Ardea Kusuma, Dedi Supriadi, dan Heppy Aprilistianto atas bantuan yang diberikan selama penelitian.

\section{DAFTAR ACUAN}

Brian, J.V., Harris, C.A., Runnalls, T.J., Fantinati, A., Pojana, G., Marcomini, A., Booy, P., Lamoree, M., Kortenkamp, A., \& Sumpter, J.P. (2008). Evidence of temperature dependent effects on the estrogenic response of fish: implications with regard to climate change. Science of the Total Environment, 397, 72-81.

Effendie, M.I. (2002). Biologi perikanan. Yayasan Pustaka Nusatama. Yogyakarta, $163 \mathrm{hlm}$.

Gaffar, A.K., \& Muflikhah, N. (1992). Pemijahan buatan dan pemeliharaan larva ikan baung. Prosiding Seminar Hasil Penelitian Perikanan Air Tawar, hlm. 254257.

Gustiano, R., Kusmini, I.I., \& Ath-thar, M.H.F. (2015). Mengenal sumber daya genetik ikan lokal air tawar Indonesia untuk pengembangan budi daya. Institut Pertanian Bogor Press, $51 \mathrm{hlm}$.

Hilder, M.L., \& Pankhurst, N.W., (2003). Evidence that temperature change cues reproductive development in the spiny damsel fish, Acanthochromispolyacanthus. Environmental Biology Fishe, 66, 187-196.

Kristanto, A.H., Subagja, J., Ath-Thar, M.H.F., Arifin, O.Z., Prakoso, V.A., \& Cahyanti, W. (2016). Pengaruh suhu inkubasi induk pada pemberian naungan pada larva terhadap produksi benih ikan baung. Prosiding Forum Inovasi Teknologi Akuakultur, hlm. 163-167.

Korner, O., Kohno, S., Schonenberger, R., Suter, M.J.F., Knauer, K., Guillette, L.J., \& Burkhardt-Holm, P. (2008). Water temperature and concomitant waterborne ethinylestradiol exposure affects the vitellogenin expression in juvenile brown trout, Salmotrutta. Aquatic Toxicology, 90, 188-196.

Kucharczyk, D., ' arski, D., Targonska, K., fuczyñski, M.J., Szczerbowski, A., Nowosad, J., Kujawa, R., $\&$ Mamcarz, A., (2014). Inducedartificial androgenesis in common tench, Tincatinca (L.), using common carp and common bream eggs. Journal Animal. Science, 13, 196-200.

Lahnsteiner, F., \& Leitner, S. (2013). Effect of temperature on gametogenesis and gamete quality in brown trout, Salmo trutta. Journal of Experimental Zoology, 319 A, 38-148.

Leesa-Nga, S.N., Daud, S.K., Sodsuk, P.K., Siraj, S.S., Tan, S.G., \& Sodsuk, S. (2000). Biochemical polymorphism in yellow catfish, Mystus nemurus (C\&V), from Thailand. Biochemical Genetics, 38, 1-9.

Levavi-Sivan, B., Bogerd, J., Manano's, E.L., Gomez, A., \& Lareyre, J.J. (2010). Perspectives on fish gonadotropins and their receptors. General and Comparative Endocrinology, 165, 412-437.

Migaud, H., Bell, G., Cabrita, E., McAndrew, B., Davie, A., Bobe, J., Herraez, M.P., \& Carrillo, M. (2013). Gamete quality and broodstock management in temperate fish. Review in Aquaculture, 5, 194-223.

Murtidjo, B.A. (2001). Beberapa Metode Pembenihan Ikan Air Tawar. Kanisius. Yogyakarta, $108 \mathrm{hlm}$.

Nowosad, J., Targonska, K., Chwaluczyk, R., Kaszubowski, R., \& Kucharczyk, D. (2014). Effect of temperature on the effectiveness of artificial reproduction of dace [Cyprinidae, Leuciscus leuciscus] under laboratory and field conditions. Journal of Thermal Biology, 45, 62-68.

Nowosad, J., Kucharczyk, D., Liszewski, T., Targonska, K., \& Kujawa, R., (2015). Comparison of temperature shock timing to induced artificial mitotic gynogenesis and androgenesis in common tench. Aquaculture International, 23(1), 45-53.

Pankhurst, N.W., \& Munday, P.L. (2011). Effect of climate change on fish reproduction and early life history stages. Marine and Freshwater Research, 62, 1015-1026.

Pankhurst, N.W., \& King, H.R. (2010). Temperature and salmonid reproduction: implications for aquaculture. Journal of Fish Biology, 76, 69-85.

Schulte, P.M. (2011). Response and adaptations to the environment (temperature). In Farrell, A.P., Cech, 
J.J.Jr., Richards, J.G., Stevens, E.D., (Eds.). Encyclopedia of fish physiology from genom to environment. Volume 3. Energetics, interactions with the environment, Lifestyles, and Applications. Inggris, Elsevier, p. 16881694.

Targonska, K., Kucharczyk, D., Kujawa, R., Mamcarz, A., \& arski, D. (2010). Controlled reproduction of Aspiusaspius (L.) using luteinizing hormone releasing hormone (LHRH) analogues with dopamine inhibitors. Aquaculture, 306, 407-410.
Vikingstad, E., Andersson, E., Norberg, B., Mayer, I., Klenke, U., Zohar, Y., Stefansson, S.O., \& Taranger, G.L. (2008). The combined effects of temperature and $\mathrm{GnRH}$ a treatment on the final stages of sexual maturation in Atlantic salmon, Salmo salar L.. Fish Physiology Biochemical, 34, 289-298.

Zohar, Y., Munoz-Cueto, J.A., Elizur, A., \& Kah, 0. (2010). Neuroendocrinology of reproduction in teleost fish. General and Comparative Endocrinology, 165, 438-455. 